\title{
Review-Essentials
}

術後䯣液漏および低髄圧症候群に対する

血液凝固第 13 因子の効果について

\section{Efficacy of Intravenous Factor XIII Administration for Postoperative Cerebrospinal Fluid Leakage and Spontaneous Intracranial Hypotension}

\author{
魚住洋 - *1,2 石原正一郎*3 甲 村 英二*1 \\ Yoichi Uozumi, M.D., Ph.D. ${ }^{* 1,2}$, Shoichiro Ishihara, M.D., Ph.D.*3, \\ Eiji Kohmura, M.D., Ph.D. ${ }^{* 1}$
}

Key words cerebrospinal fluid leakage intracranial hypotension Factor XIII

\section{はじめに}

脊髄外科手術，脳神経外科手術の術後髄液漏は，その 治療が一筋縄ではいかない症例も少なくなく, 可能なか ぎり避けたい合併症の 1 つである．特に髄液漏出部位の 特定が困難な場合や，再手術による髄液漏出部位の閉鎖 が困難な場合は治療に難渋する。低髄圧症候群は, 起立 性頭痛に代表される諸症状をきたす疾患で，その治療は 診断基準に基づき髄液漏出部位が確認された患者には硬 膜外腔に自己血を注入するブラッドパッチ（以下，ブ ラッドパッチ）が有効とされる ${ }^{1,2)}$. ブラッドパッチは 2016 年 4 月に「硬膜外自家血注入」として保険収載され た。しかし，低髄圧症候群の患者の中には少なからずブ ラッドパッチ無効例が存在することから ${ }^{1,3)}$ ，ブラッド パッチ以外の治療法も望まれるところである.

血液凝固第 13 因子（以下，第 13 因子）は，1948 年 Laki $ら^{4)}$ によって発見された血液凝固因子の 1 つで, 凝 固の最終段階でフィブリン分子間の架橋形成を触媒する ことで強固なフィブリン網形成の触媒として止血を完成 させる役割を果たす一方，創傷治癒過程においても線維 芽細胞増殖抢よび表皮形成を促進させることで大きな役 割を果たす䤉素である ${ }^{5 \sim 7)}$. 脳神経外科領域では, 術後 の髄液漏に対する有効性が症例報告として散見されるほ か $^{8 \sim 10)}$, 低髄圧症候群に対する第 13 因子投与の有効性を 示す報告がある11,12).
本稿では第 13 因子の基本的事項，および第 13 因子の 術後髄液漏と低髄圧症候群に対する治療効果について文 献的考察を加えて概説する。

\section{1. 血液凝固第 13 因子とその働き}

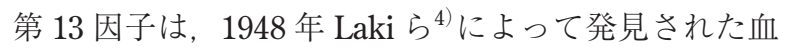
液凝固因子の 1 つで, 触媒部位をもつ A サブユニット二 量体とそれを保護する Bサブユニット二量体からなる異 種四量体として血中を循環している ${ }^{13)}$.

第 13 因子の生体内での役割が明確になったのは, Duckert らが先天性の第 13 因子欠損症を報告した 1960 年以降のことである ${ }^{5,6)}$. 先天性第 13 因子欠損症は, 出 血, 創傷治癒遅延, 習慣性流産が 3 主徵であることから もわかる通り，臨床的には第 13 因子は止血および創傷治 癒に関与している。

第 13 因子は凝固の最終段階でトロンビンにより活性 化され，フィブリン分子間の架橋形成を触媒することで 強固なフィブリン網形成の触媒として止血を完成させる 役割を果たす一方，創傷治癒過程においては上記フィブ リン網上に線維芽細胞が増殖し肉芽組織が形成され創傷 治癒を促進させることに大きな役割を果たす酵素であ $b^{6)}$. 手術侵襲や出血により第 13 因子活性が低下し, そ の結果出血傾向や創傷治癒遅延・瘦孔などをきたす。こ れらの症状は，第 13 因子の補充で軽快することが知られ

\footnotetext{
*1 神戸大学大学院医学研究科脳神経外科分野 /Department of Neurosurgery, Kobe University Graduate School of Medicine 連絡先： ₹ 650-0017 神戸市中央区楠木町 7-5-2 神戸大学大学院医学研究科脳神経外科分野 魚住洋一〔Address reprint requests to : Yoichi Uozumi, M.D., Ph.D., Department of Neurosurgery, Kobe University Graduate School of Medicine, 7-5-2, Kusunoki-cho, Chuo-ku, Kobe-shi, Hyogo 650-0017, Japan]

*2 北播磨総合医療センター脳神経外科 /Department Neurosurgery, Kita-Harima Medical Center

*3 埼玉石心会病院脳神経外科/Department Neurosurgery, Saitama Sekishinkai Hospital
} 
ている ${ }^{14 \sim 16)}$. 本邦に打ける第 13 因子製刜の適応は, 1980 年に先天性第 13 因子久損症に対して承認以降, 1985 年に血液第 13 因子の低下に伴う縫合不全および瘦 孔に, 1992 年に Henoch-Schönlein 紫斑病における腹部 症状, 関節症状の改善に, 2013 年には後天性第 13 因子 欠乏症にそれぞれ追加適応症承認されている.

脳神経外科領域では Gerlach ら ${ }^{17)}$ が 876 症例, 910 回 の開頭手術を前方視的に検討した結果，39手術（4.3\%） に術後出血を認め, 非出血群と比較して術前・術後とも に出血群は第 13 因子活性が有意に低值であり, 術後出血 の相対危険度は第 13 因子活性が $80 \%$ 未満では 3.9 倍に, $60 \%$ 以下では 6.4 倍に上昇すると報告している，さらに ほかの凝固因子は正常範囲であることが多く, 通常の術 前採血の凝固系スクリーニングでは異常がみつからない と注意喚起している. Bosche ら ${ }^{18)}$ は特発性の慢性硬膜 下血腫における第 13 因子との関連を前方視的に検討し 報告している。117 例の慢性硬膜下血腫のうち外傷既往 のない特発性慢性硬膜下血腫 18 例と外傷性慢性硬膜下 血腫の第 13 因子活性を測定したところ，65\% vs $93 \%$ と 特発性慢性硬膜下血腫群は有意に第 13 因子活性が低く, 特発性慢性硬膜下血腫 18 例中 6 例に再出血がみられた。 また, 再出血を繰り返した脳出血患者で, 第 13 因子欠乏 が後の精查で判明したとの症例報告がある ${ }^{19)}$. 本邦から は再出血のため治療に難淽した急性硬膜下血腫症例にお いて, 第 13 因子欠乏が後の精査で判明したとの症例報告 が複数みられる20,21).

\section{2. 術後髄液漏に対する第 13 因子の効果につ いて}

術後髄液漏に対する第 13 因子の有効性が, 症例報告と して散見される。頭蓋底外科手術後の髄液漏に第 13 因子 が有効であったとの症例報告がなされているほか, 経蝶 形骨洞手術後の髄液漏に第 13 因子が有効とする報告も 複数ある ${ }^{8 \sim 10)}$. 土持 $ら^{9)}$ は, 経蝶形骨洞的腫瘍摘出およ び開頭腫瘍摘出後 $4 \sim 5$ 日後（1例で時期不明確）に䯣液 漏を生じ，血漿第 13 因子活性が $70 \%$ 以下であった 4 症 例について第 13 因子を投与したところ, 保存的加療で髄 液漏が治癒したと報告している。河村ら ${ }^{8}$ は小脳橋角部 の巨大髄膜腫を経錐体骨到達法で腫瘍摘出を行い, 術 1 週間後に髄液漏を生じ, 2 週間の安静腰椎ドレナージ管 理を行ったが髄液漏が改善しなかった症例に対して, 血 漿第 13 因子活性を測定したところ 30\%以下に低下して いた，その症例に対して第 13 因子製剤を投与したとこ ろ，投与から 1 週間で治癒したと報告している，頭蓋咽 頭腫に対して拡大蝶形骨洞手術を行った 10 日後に䯣液
漏を生じた症例に対して, 押野ら ${ }^{10)}$ は血漿第 13 因子活性 を測定し $52 \%$ と活性が低下していたため，第 13 因子製 剂を投与し 1 週間で治癒したと報告している.

第 13 因子久乏による髄液漏を疑った場合は, まず血漿 第 13 因子活性を測定する. 正常の 70\%以下に低下して いる場合は, 血漿由来の第 13 因子濃縮製剂（240 単位） バイアル）を外科領域の止血や瘦孔閉鎖目的で使用する 場合と同量の 1 日 3 6 ベイアル，連日 5 日間投与し，投 与完了後 1 週間程度かけて臨床症状, 画像検査などで効 果判定する.

\section{3．低髄圧症候群について}

低髄圧症候群とその治療を取り巻く諸事情について, 簡単にまとめたい，低髄圧症候群（intracranial hypotension)はSchaltenbrand ${ }^{22)}$ が 1938 年に報告して以来, 1990 年代に多数の研究によりその病態生理の解明が進ん だ2，低髄圧症候群の症状を示す患者の中に，正常の脑 脊髄液圧を示すものが少なからずいることから，脳脊髄 液減少症（intracranial hypovolemia）や，その病態生理 から脳脊髄液漏出症（cerebrospinal fluid leak）とも呼ば れる。これらの疾患名の通り, 低髄圧症候群は脳脊髄液 漏出に伴い頭蓋内圧が低下することで，起立性頭痛をは じめとする諸症状を生じる，低髄圧症候群の理解につい ては優れた総説があるため, そちらを参考にしていたた きたい ${ }^{2,23 \sim 25)}$. 現在診断基準は複数あり, 内容も作成し た団体によってさまざまである。現在臨床現場で頻用さ れる診断基準は，おもに4つと考えられる。(1)国際頭痛 学会による国際頭痛分類第 2 版 ${ }^{26)}$, (2)国際頭痛分類をも とに外傷との関倸性を追加した日本脳神経外傷学会の 「外傷に伴う低髄液圧症候群作業部会」が作成した診断基 準 (http://www.neurotraumatology.jp)，(3)日本脳神経外 科学会が中心となり，低髄液圧症候群の診断治療に関連 する学会・専門家などで構成された「脳脊髄液減少症の 診断・治療法の確立に関する研究班」が公表した「脑脊 髄液漏出症」の画像判定基準・画像診断基準 ${ }^{27)}$, (4)日本 脳脊髄液減少症研究会による「脳脊髄液減少症ガイドラ イン」である28)，それぞれの立場で作成された診断基 準・治療ガイドラインであるが, その作成の背景や経緯 については佐藤らの報告に詳しくまとめられており, 一 読をおすすめする3,27).

ブラッドパッチは 1960 年, Gormley ${ }^{29)}$ により腰椎麻酔 後頭痛に対する治療として報告された。彼は traumatic tap となった腰椎穿刺後の患者群には頭痛の訴えが少な いことに着目し，腰椎麻酔後頭痛を訴える患者 7 名に対 して硬膜穿刺部位と同じ高位の硬膜外腔に患者の自己血 

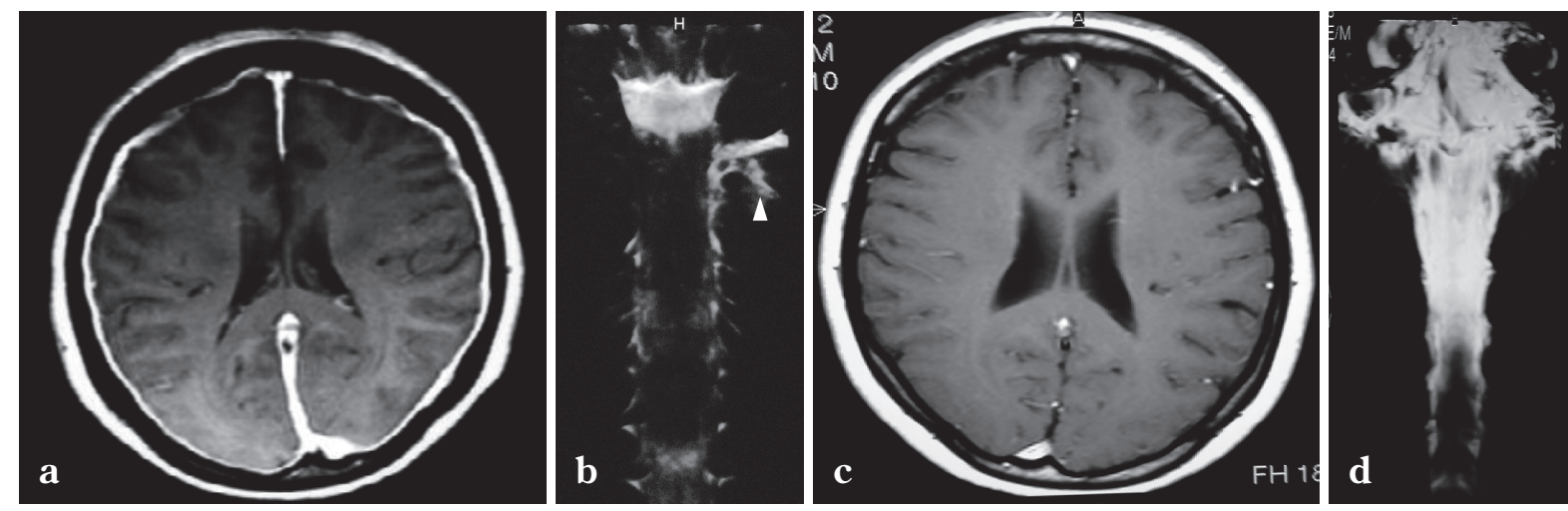

Fig. 1 起立性頭痛で発症した, 特発性低䯣圧症候群の 38 歳, 女性

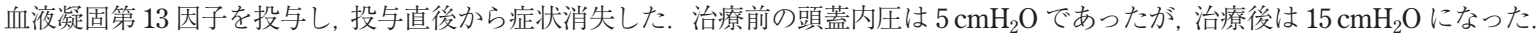

a ：治療前頭部造影 $\mathrm{T} 1$ 強調画像. びまん性硬膜肥厚を認める

b : 治療前 MR ミエログラフィー。上位頚髄から漏出する髄液を認める (矢頭).

c：治療後頭部造影 $\mathrm{T} 1$ 強調画像. びまん性硬膜肥厚は消退している.

d ：治療後 MR ミエログラフィー。髄液の漏出は認めない.

を数 $\mathrm{m} l$ 投与したところ，直後から頭痛が軽快したと報 告した．特発性低髄圧症候群に対するブラッドパッチの 報告は, 1987 年に Gaukroger ら ${ }^{30)}$ によりもたらされた. 本邦では 1998 年に朝倉ら ${ }^{31)}$ によって最初の報告がなさ れた。

2016 年 4 月以降, (3)の診断基準に伴い脳脊髄液漏出症 と確定診断されれば保険診療としてブラッドパッチを行 うことができる。2006 年の第 65 回日本脳神経外科学会 総会で, 学会として脳脊髄液減少症の研究に着手すると 宣言がなされた後, 厚生労働省研究事業を通じて 10 年が かりで保険収載されたブラッドパッチであるが，「関係 学会の定める脳脊髄液漏出症の画像診断基準に基づき脳 脊髄液漏出症として『確実』または『確定』と診断され たものに対してのみ算定できる」とされており，診療報 酬請求にあたっては, 診療報酬明細書に当該診断基準を 満たすことを示す画像所見, 撮影日, 撮影医療機関の名 称などの症状詳記を添付することが求められている。つ まり, 低髄圧症候群の患者でも画像診断で髄液漏出部位 が特定できない患者には, ブラッドパッチは保険治療の 適応とならない，さらに，抗凝固療法中の症例や脊椎 · 春髄手術後で硬膜外腔の癒着が疑われる症例などには, 治療を躊躇する場合があると思われる。また，ブラッド パッチの合併症として, 施行中の血圧低下や徐脈, 意識 障害, 施行中・後の腰背部痛, 施行後の感染や硬膜外腔 癒着に伴う神経炎があることも無視できない4,32).

\section{4. 低髄圧症候群に対する第 13 因子の効果に ついて}

少ない症例ながら，低髄圧症候群に対する第 13 因子の
有効性が報告されている. 瘦孔閉鎖に効果がある第 13 因 子をIshihara ${ }^{11)}$ は安静臥床と補液を行っても改善しな い特発性低髄圧症候群の患者 2 例に投与し, 症状が軽快 したと報告した。代表症例の画像を提示する（Fig. 1). その後, 同施設の Nagatani ら ${ }^{12)}$ は第 13 因子を用いて治 療した特発性低髄圧症候群の患者合計 11 例のうち, Ishihara らが当初報告した 2 例を除く 9 例の治療結果を まとめて報告した，対象は起立性頭痛をはじめとする臨 床症状扮よび頭部 MRI，脊髄 MRI，MRミエログラ フィー, 脳槽シンチグラフィーで特発性低髄圧症候群と 診断された患者のうち， 1 週間の安静臥床および補液を 行っても症状が軽快しなかった 9 症例（平均年齢 42.3 歳, 男: 女 $=4: 5)$ である。血漿由来の第 13 因子濃縮製 剂（240 単位/バイアル）を1日 5バイアル，5１0日間 連続で投与した。結果, 6 例で頭痛の完全寛解が得られ， 2 例で頭痛改善, 1 例が不変であり, 頭痛が悪化した症例 はなかった，治療前の第 13 因子活性は平均 89\%（62～ 138\%)，治療後のそれは平均 156\%（109２82\%）であっ た. 第 13 因子投与に伴う副作用は認めなかった。

特筆すべきは，投与前の第 13 因子活性が $70 \%$ 以上の 症例 3 例中すべての症例で第 13 因子投与により頭痛の完 全宽解が得られたこと，および画像診断で髄液漏出部位 が特定できなかった 2 症例でも第 13 因子投与により症状 が軽快したことである（1例完全宽解，1例症状改善）。 これらより外科侵襲の加わっていない特発性低髄圧症候 群の患者に打ける第 13 因子活性には個体差によるばら つきが示唆されること，また特発性低髄圧症候群の病態 生理に関してさらなる理解が必要であることが示されて いる. 
血漿第 13 因子活性は通常，70１30\%程度とされてい $3^{13)}$ 。腹部外科侵襲後の第 13 因子活性は術後 50 ～60\% 程度まで低下することが知られているが ${ }^{14 \sim 16)}$, 外科侵 襲のない疾患群で第 13 因子活性が変化するか否か報告 がない. Nagataniらの報告はその点で貴重と考えられる.

特発性低髄圧症候群の原因はいまだ明らかになってい ないが，解剖学的に脆弱な脊髄神経根周囲の髄膜から髄 液が漏れることが原因であろうと推察されている21. ブ ラッドパッチが保険適応となった現在の本邦では，低髄 圧症候群が疑われた患者に対して前述(3)の診断基準に基 づき髄液漏出部位の特定が図られていることと思われ る。しかし, 臨床症状から低髄圧症候群が強く疑われて も画像検査で髄液漏出部位が特定できない特発性低髄圧 症候群も，一定の割合で経験する。この原因としては, さまざまな可能性が考えられるが，その 1 つとして脊髄

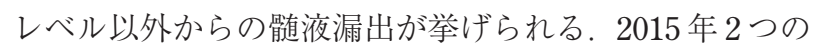
異なる研究グループからほぼ同時期に「硬膜にはリンパ 管構造があり, 䯋液はこの硬膜リンパ管を通じて媣澒り ンパ節へ排泄される」との報告がなされた ${ }^{33,34)}$.中でも Aspelund ${ }^{34)}$ は, 硬膜リンパ管は円蓋部硬膜には疎で頭 蓋底神経孔周囲硬膜に密に発達しており, 動脈, 静脈, 神経に沿うように走行していると硬膜内リンパ管の分布 とその働きを報告している.

これらの知見から，低髄圧症候群の患者の一部におい て髄液は脊髄レベルの神経根周囲から漏出するだけでは なく, 脳神経周囲から漏出している可能性もあると推察 される. 現在の診断基準で推奨される検查はいずれも脊 髄レベルでの髄液漏出部位の検出に絞られており, 頭蓋 底からの髄液漏出には注目されていない。これが一部の 低髄圧症候群患者の漏出部位特定にいたらない原因の 1 つではないだろうか，さらに，頭蓋底レベルで髄液が過 剩に漏出しているのだとすれば, 脊髄レベルから自家血 を注入するブラッドパッチが無効であることもうなずけ る。漏出部位を選ばず創傷治癒促進・瘦孔閉鎖の効果が 得られる第 13 因子の投与は, こういった漏出部位特定が 困難な低髄圧症候群に対しても効果が得られる一因と なっていると思われる。

なお，現時点で，第 13 因子は低髄圧症候群に対する保 険治療の適応はないことを申し添える。

\section{まとめ}

術後髄液漏, 低髄圧症候群の治療オプションとして創 傷治癒促進・㾇孔閉鎖の効果がある血液凝固第 13 因子の 投与は一考に值すると思われる.

本拙文が皆様の日常臨床の一助となれば幸甚です.

\section{利益相反開示}

著者全員は日本脳神経外科学会への COI 自己申告の登録を 完了しています。本論文に関して開示すべき COI はありませ ん.

\section{文 献}

1) Berroir S, Loisel B, Ducros A, et al : Early epidural blood patch in spontaneous intracranial hypotension. Neurology $\quad 63: 1950-$ 1951, 2004

2) Schievink WI : Spontaneous spinal cerebrospinal fluid leaks and intracranial hypotension. JAMA $295: 2286-2296,2006$

3）佐藤慎哉：厚生労働省研究事業の総括. 脊椎脊髄 29 : 926931, 2016

4) Laki K, Lóránd L : On the Solubility of Fibrin Clots. Science 108:280, 1948

5) Duckert F, Jung E, Shmerling DH : A hitherto undescribed congenital haemorrhagic diathesis probably due to fibrin stabilizing factor deficiency. Thromb Diath Haemorrh 5 : 179-186, 1960

6) Beck E, Duckert F, Ernst M : The influence of fibrin stabilizing factor on the growth of fibroblasts in vitro and wound healing. Thromb Diath Haemorrh 6 : 485-491, 1961

7) Richardson VR, Cordell P, Standeven KF, et al : Substrates of Factor XIII-A : roles in thrombosis and wound healing. Clin Sci (Lond) 124:123-137, 2013

8）河村淳史, 玉木紀彦, 米澤一喜, 他 : 経錐体骨到達法による 腫瘍全摘出術後難治性髄液漏に対し血液凝固第X而因子製剂が 著効を示した 1 例. No Shinkei Geka 24:1107-1111，1997

9）土持廣仁，福島武雄，阪元政三郎，他：術後䯣液漏に対する 保存的療法一血液凝固第 13 因子による新治療法. Biomedical Perspectives 3:75-80, 1994

10）押野 悟, 重松朋芳, 齋藤洋一：フィブロガミン $\mathrm{P}$ 症例 脳 神経外科領域 拡大経蝶形骨洞手術後の髄液漏に対し, フィ ブロガミン P が有効であった 1 例. Medical Torch 8:4445, 2012

11) Ishihara $\mathrm{S}$, Fukui $\mathrm{S}$, Otani $\mathrm{N}$, et al : Evaluation of spontaneous intracranial hypotension : assessment on ICP monitoring and radiological imaging. Br J Neurosurg $15: 239-241,2001$

12) Nagatani $K$, Takeuchi $S$, Wada $K$, et al : Treatment of spontaneous intracranial hypotension with intravenous Factor XIII administration : initial clinical experience. Turk Neurosurg $25: 69-$ 72,2015

13）一瀬白帝: 凝固 13 因子関連疾患の基礎と臨床一とくに後天性 血友病 13 (出血性後天性凝固 13 因子欠乏症）について。日 小児血液会誌 $24: 3-13,2010$

14）武藤輝一, 石引久弥：BI71.023（フィブロガミン P) の消化 器外科手術後の㾇孔および縫合不全に対する有効性および安 全性の臨床的検討。新薬と臨 $44: 26-42,1995$

15）第XII因子研究会, 三島好雄, 東京大学医学部第一外科 : 手術 侵襲とXIII因子の術後変動一第一報. 最新医学 $36: 2492-$ 2495,1981

16）第覌因子研究会, 三島好雄, 東京大学医学部第一外科: 難治 性創傷治癒不全患者に対する XII因子の治療効果一第二報. 最 新医学 $36: 2496-2505,1981$

17) Gerlach R, Tölle F, Raabe A, et al : Increased risk for postoperative hemorrhage after intracranial surgery in patients with decreased factor XIII activity : implications of a prospective study. Stroke $33: 1618-1623,2002$

18) Bosche B, Molcanyi M, Noll T, et al : Occurrence and recurrence of spontaneous chronic subdural haematoma is associ- 
ated with a factor XIII deficiency. Clin Neurol Neurosurg 115 : 13-18, 2013

19) Perez DL, Diamond EL, Castro CM, et al : Factor XIII deficiency related recurrent spontaneous intracerebral hemorrhage $: \mathrm{a}$ case and literature review. Clin Neurol Neurosurg $113: 142-$ 145,2011

20) Kawano H, Yamamoto D, Uchihashi Y, et al : Severe inhibitornegative acquired factor XIII/13 deficiency with aggressive subdural haemorrhage. Blood Coagul Fibrinolysis 24 : 638-641, 2013

21）大谷理浩, 井上 智, 馬越通有, 他 : 急性硬膜下血腫の術後 に繰り返す後出血から第 13 因子久そ症と診断した 1 例. 脳外 速報 23: 1390-1394， 2013

22) Schaltenbrand $G$ : Neuere anschauungen zur pathophysiologie der liquorzirkulation. Zentralbl Neurochir $3: 290-300,1938$

23) Rando TA, Fishman RA : Spontaneous intracranial hypotension : report of two cases and review of the literature. Neurology $42: 481-487,1992$

24）石坂秀夫, 松前光紀: 特発性脳脊髄液減少症. No Shinkei Geka $34: 453-460,2006$

25）島 克司：特発性低髄液圧症候群：病態と診断・治療。神経 外傷 $30: 7-13,2007$

26）国際頭痛学会·頭痛分類委員会：国際頭痛分類 第 2 版. 日 頭痛会誌 $31 ： 13-188,2004$
27）佐藤慎哉, 嘉山孝正 : 低髄液圧症候群, 脳脊髄液減少症, 脑 春髄液漏出症．䑈外誌 $22: 443-451,2013$

28）脳脊髄液減少症研究会ガイドライン作成委員会：脳脊髄液減 少症ガイドライン 2007. 東京, メデイカルレビュー社, 2007, pp15-18

29) Gormley JB : Treatment of Post Spinal Headache. Anesthesiology $21: 565-566,1960$

30) Gaukroger PB, Brownridge P : Epidural blood patch in the treatment of spontaneous low CSF pressure headache. Pain 29 : 119-122, 1987

31）朝倉美香, 丹野 英, 永井利恵, 他：特発性低髄圧症候群に 対し硬膜外自家血パッチを試みた 2 症例。麻酔 $47: 1243-$ 1245,1998

32) Desai MJ, Dave AP, Martin MB : Delayed radicular pain following two large volume epidural blood patches for post-lumbar puncture headache : a case report. Pain Physician $13: 257-$ 262,2010

33) Louveau A, Smirnov I, Keyes TJ, et al : Structural and functional features of central nervous system lymphatic vessels. Nature 523 : 337-341, 2015

34) Aspelund A, Antila S, Proulx ST, et al : A dural lymphatic vascular system that drains brain interstitial fluid and macromolecules. J Exp Med 212 : 991-999, 2015 